\title{
STATEMENT OF OWNERSHIP, MANAGEMENT AND CIRCULATION
}

Act of October 23, 1962; Section 4369, Title 39, United States Code

1. Date of filing: September 1, 1969

2. Title of Publication: The Bulletin of the American Mathematical Society

3. Frequency of issue: Bi-monthly

4. Location of known office of publication: 321 South Main Street, Providence, P.O. Box 6248,

5. Location of the Headquarters of General Business Office of the Publishers: Same

6. Names and Addresses of Publisher, Editor, and Managing Editor: Publisher, American Mathematical Society, 321 South Main Street, P.O. Box 6248, Providence, Rhode Island 02904; Editor, Murray Gerstenhaber,
64 Clover Lane, Princeton, New Jersey 08540; Managing Editor, None.

7. Owner: American Mathematical Society, 321 South Main Street, P.O. Box 6248, Providence, Rhode Island 02904.

8. Known Bondholders, Mortgages and Other Security Holders Owning or Holding 1 Percent of More of Total Amount of Bonds, Mortgages or Other Securities: None.

9. The purpose, function, and nonprofit status of this organization and the exempt status for Federal income tax purposes have not changed during the preceding 12 months.

10. Extent and Nature of Circulation:

\section{Actual No. Copies \\ Average No. Copies of Single Issue \\ Each Issue During Published Nearest \\ Preceding 12 Months Filing Date}

A. Total No. Copies Printed.......... 15,300 15,400

B. Paid Circulation

1. Sales through dealers and carriers, street venders and counter sales. .

2. Mail Subscriptions.............

C. Total Paid Circulation.............

D. Free Distribution................

F. Office Use, Left-over, Unaccounted, Spoiled After Printing..............

G. Total. . . .

I certify that the statements made by me above are correct and complete. Gordon L. Walker. 